JOSAR, Vol. 1 No. 1 March, 2018; p-ISSN: 2502-8251; e-ISSN: 2503-1155

Copyrights@ Balitar Islamic University, Blitar-Indonesia

https://ejournal.unisbablitar.ac.id/index.php/josar

\title{
APPLICATION OF STRING MATCHING USING BOYER MOORE ALGORITHM IN THE APPLICATION OF DICTIONARY LIVESTOCK TERMS
}

\author{
Wahyu Suci Saputri ${ }^{1}$, Riska Dhenabayu ${ }^{2)}$, Filda Febrinita ${ }^{3)}$ \\ 1,2Islamic University of Balitar; Jl. Majapahit No.04, Telp. (0342) 813145 \\ ${ }^{3}$ Program Studi Teknik Informatika, FTI Universitas Islam Balitar, Blitar \\ e-mail: sifuth01@gmail.com ${ }^{1)}$, dhenabayu@gmail.com ${ }^{2}$, febrinitafilda@gmail.com $^{3)}$
}

\begin{abstract}
Difficulty in getting a dictionary of the term livestock is an obstacle for the academic community of the Faculty of Animal Husbandry, Balitar Islamic University to find out the meaning of the term livestock. Along with the progress of the times, the need for a dictionary can certainly be met with technological sophistication, one of which is through a dictionary application. This study designed the term dictionary dictionary application by applying the Boyer Moore algorithm matching string. This translation process is carried out in the form of words where each keyword term searched will appear along with the meaning of the term farm. The term farm dictionary application is designed using Microsoft Visual Visio 2007 and the application is implemented based on the website. The boyer moore string matching algorithm does word matching by applying the FilterString function and the search function. The FilterString function detects each character in a keyword while the search function matches keywords from the FilterString function with terms in term data in the database. The results of beta testing showed that the system obtained an average value of $71.58 \%$, meaning that users had high satisfaction with the term dictionary application.
\end{abstract}

\section{Keywords - Boyer Moore, Terms, Dictionaries, Farms, String Matching}

\section{INTRODUCTION}

Dictionaries are words and expressions in a reference book that are usually arranged in alphabetical order $A-Z$ along with a description of the meaning of the word, the use of words and the translation of the word [1]. The term dictionary is a dictionary that contains terms from a particular field of science such as dictionaries of terms of technical science and dictionaries of the term livestock science [1]. Law No.18 of 2009 explains that livestock is all matters related to physical resources, seeds, seeds, animal feed, livestock tools or machinery, livestock cultivation, crop yields, post-harvest, livestock processing, livestock marketing, and livestock farming [business]. 2]. 
From the results of interviews conducted by researchers with Ms. Nita Opi A.K, Spt, MMA as Dean of the Faculty of Animal Husbandry at Balitar Islamic University, the need for livestock academics for the dictionary of the term livestock is still very high. Along with the progress of the times, the need for a dictionary can certainly be fulfilled by utilizing the technological sophistication of one of them through the internet. According to data released by the social marketing agency "We Are Social", active internet users in Indonesia in 2016 reached 88.1 million and $70 \%$ of them accessed via mobile devices [3]. To obtain information from the internet, users need to type in keywords that are searched for on search engines, for example Google.

Google as a search engine with the most users, is able to provide various kinds of information based on keywords typed by users [4]. Researchers conducted a search through Google to find a dictionary application for the term farm or dictionary for the term online farming. However, until now researchers have not found the farm dictionary. Therefore, researchers will use a string matching algorithm, namely Boyer Moore algorithm to build a farm dictionary application. The Boyer Moore algorithm is considered to be one of the most efficient and appropriate algorithms for matching strings between other algorithms [5].

The boyer moore algorithm compares patterns with matching matching strings from the rightmost character to the far left position [6]. The boyer moore algorithm is different from similar string matching algorithms that start searching words from left to right. This algorithm applies the good suffix principle (where the character being searched is aligned with the character that resembles it) and the principle of bad character (where if the character has no resemblance it will be eliminated immediately) [7].

Based on the background described earlier, the dictionary of the term livestock is considered as an alternative solution that can help solve 
JOSAR, Vol. 1 No. 1 March, 2018; p-ISSN: 2502-8251; e-ISSN: 2503-1155

Copyrights@ Balitar Islamic University, Blitar-Indonesia https://ejournal.unisbablitar.ac.id/index.php/josar

problems faced by the livestock academics. The dictionary application of the term farm will be built by implementing the Boyer Moore algorithm on the search term. Therefore, the researcher conducted a study with the title "Application of String Matching Using the Boyer Moore Algorithm in the Application of the Dictionary of Animal Husbandry".

\section{RESEARCH METHODS}

\section{A. Time and Place of Research}

The research was conducted at the Faculty of Animal Husbandry, Balitar Islamic University, located on JI. Majapahit No.04 Ex. Sanan Wetan Kec. Sanan Wetan Blitar City between February - July 2018.

\section{B. Data Collection Method}

The method used to collect information is carried out in the following stages:

1. Observation

Conduct observations and observations directly during March-April 2018 at the Faculty of Animal Husbandry, Blitar Balitar Islamic University to obtain data.

2. Interview

The primary data from the method of data collection is interviews, which were conducted to Ms. Nita Opi A.K, Spt, MMA as Dean of the Faculty of Animal Husbandry, Balitar Islamic University.

3. Library Studies

Secondary data is obtained from national journals and international journals as well as from scientific books both printed and e-book, thesis reports, and other scientific essays. 
JOSAR, Vol. 1 No. 1 March, 2018; p-ISSN: 2502-8251; e-ISSN: 2503-1155

Copyrights@ Balitar Islamic University, Blitar-Indonesia https://ejournal.unisbablitar.ac.id/index.php/josar

\section{System Design Methods}

1. Flowchart

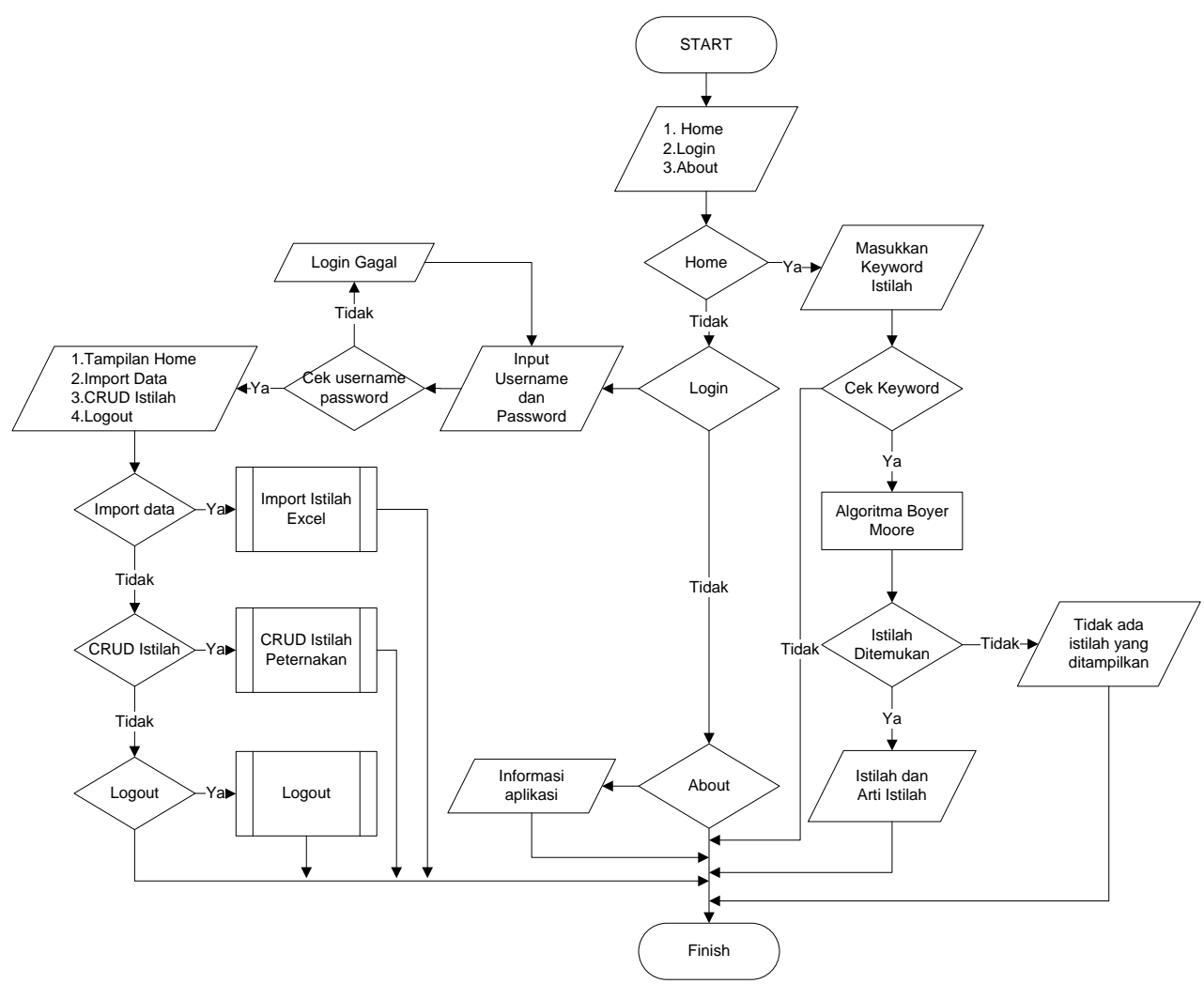

Figure 1 Flowchart Application Program Dictionary of Animal Husbandry Terms

Explanation of Flowchart in figure 1:

\section{a. Start}

Start is the beginning to start the Flowchart. Users use this application with the main menu display containing the term search form using the Boyer Moore algorithm. The home page also selects the admin login menu option and the about menu. The about menu can be accessed by all users while the admin login menu can only be used by the admin for access to the admin page 
JOSAR, Vol. 1 No. 1 March, 2018; p-ISSN: 2502-8251; e-ISSN: 2503-1155

Copyrights@ Balitar Islamic University, Blitar-Indonesia https://ejournal.unisbablitar.ac.id/index.php/josar

b. Finish

Finish is the final flowchart menu.

A

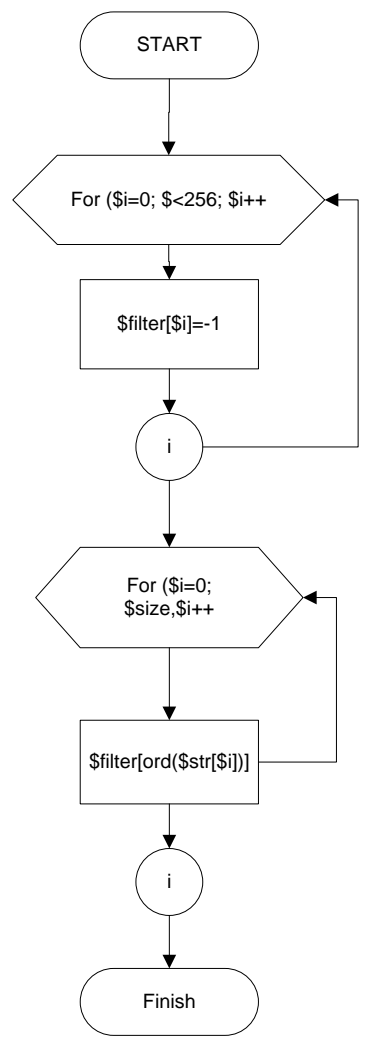

B

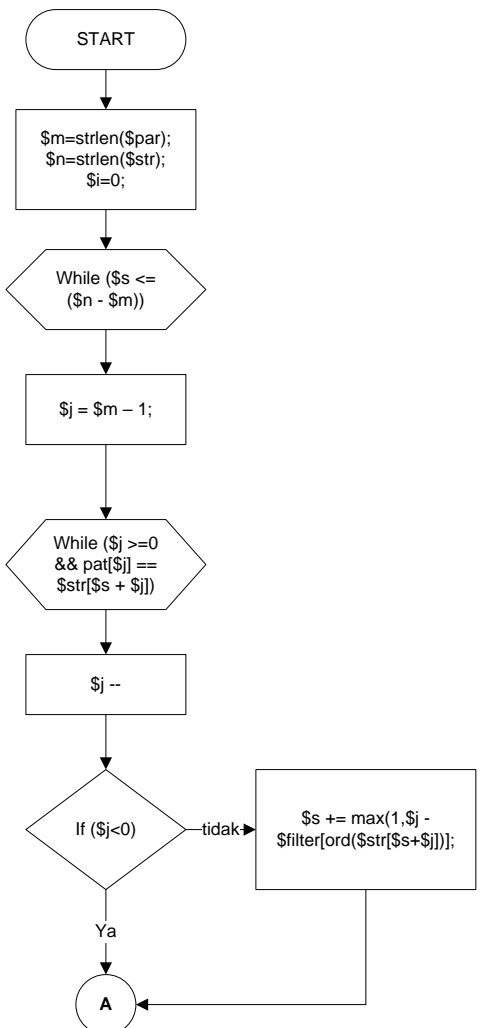

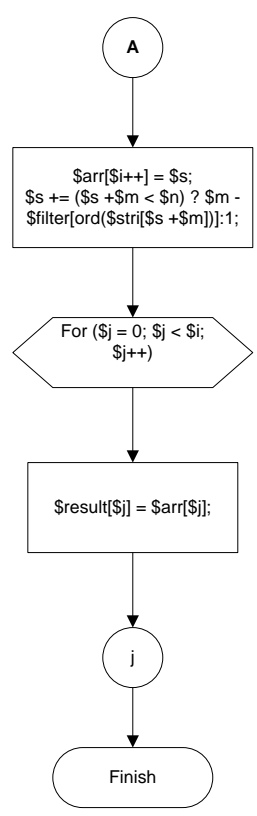

Figure 2 Flowchart Algorithm Boyer Moore

Explanation of Flowchart in figure 1:

a. Start

Start is the beginning to start the Flowchart.

b.Menu

Part A describes the flow to filter the keywords entered by the user. The first step is by initializing the loop in detecting each character on the keyword entered by the user. The second step with initialization containing keywords that are filtered from the previous initialization is then converted (conversion) to ASCII values on the keyword character.

Part B shows the search function for the Boyer Moore algorithm, starting with the system to process to calculate the pattern length (keywords) and string length (term data) in the database. The next step is to 
JOSAR, Vol. 1 No. 1 March, 2018; p-ISSN: 2502-8251; e-ISSN: 2503-1155

Copyrights@ Balitar Islamic University, Blitar-Indonesia https://ejournal.unisbablitar.ac.id/index.php/josar

initialize $s$ to calculate the shift by converting the ASCII value from the

term data then compared to the filtered keyword.

c. Finish

Finish is the final flowchart menu

\section{RESULT AND DISCUSSION}

In the term farm dictionary application that applies the Boyer Moore algorithm, users access the application online. The user searches by typing in the keyword farm term on the search form as shown in Figure 3:

\section{CARI ISTILAH}

Figure 3 Form the keyword search term for livestock

Then after entering the keyword term livestock, the user will press the search button term then the term dictionary application farm will display the term that matches the keyword along with its translation like figure 4:

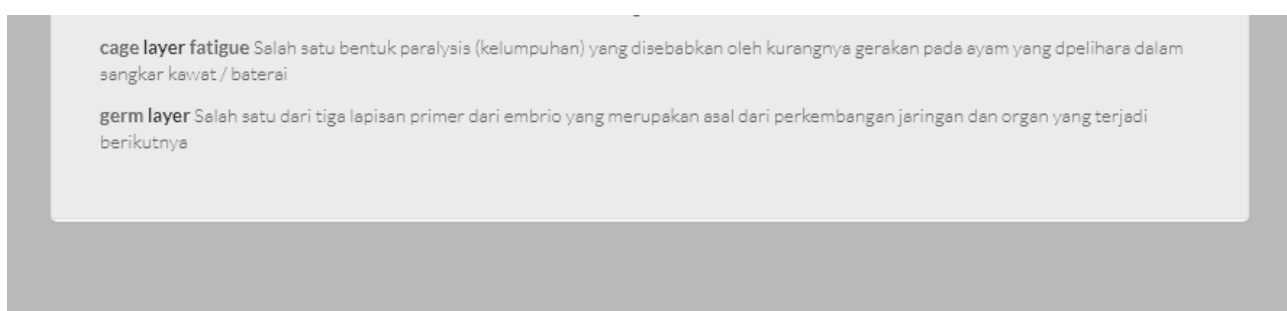

\section{Figure 4 term search results on the application}

To prove the efficiency and accuracy of searches with the Boyer Moore algorithm in the dictionary application of the term farm, testing was carried out. Algorithm testing is done by entering keywords in the search form and the application will display the terms that match the keywords. The accuracy and number of terms displayed in the application will be calculated and the results will show the level of efficiency of using the Boyer Moore algorithm.

Table 1 Testing the efficiency of the Boyer Moore algorithm

\begin{tabular}{lllllll}
$N$ & Pertanyaan & \multicolumn{3}{c}{ Banyak istilah yang ditampilkan } & Hasil \\
\cline { 3 - 5 } & $<10$ & $<25$ & $<50$ & $>50 \quad>100$ & Terting
\end{tabular}


JOSAR, Vol. 1 No. 1 March, 2018; p-ISSN: 2502-8251; e-ISSN: 2503-1155

Copyrights@ Balitar Islamic University, Blitar-Indonesia https://ejournal.unisbablitar.ac.id/index.php/josar

\begin{tabular}{|c|c|c|c|c|c|c|c|}
\hline & & & & & & & gi \\
\hline 1 & $\begin{array}{l}\text { Enter the } \\
\text { keyword farm } \\
\text { term with } 1 \\
\text { letter and how } \\
\text { many results } \\
\text { are the terms } \\
\text { displayed in the } \\
\text { application? }\end{array}$ & $\begin{array}{c}23.81 \\
\%\end{array}$ & $\begin{array}{c}4.76 \\
\%\end{array}$ & $\begin{array}{c}3.17 \\
\%\end{array}$ & $\begin{array}{c}15.87 \\
\%\end{array}$ & $\begin{array}{c}52.38 \\
\%\end{array}$ & $52.38 \%$ \\
\hline & $\begin{array}{l}\text { Enter the } \\
\text { keyword farm } \\
\text { term with } 5\end{array}$ & $\begin{array}{c}55.56 \\
\%\end{array}$ & $\begin{array}{c}19.05 \\
\%\end{array}$ & $\begin{array}{c}7.94 \\
\%\end{array}$ & $\begin{array}{c}11.11 \\
\%\end{array}$ & $\begin{array}{c}6.35 \\
\%\end{array}$ & $55.56 \%$ \\
\hline 2 & $\begin{array}{l}\text { letters and how } \\
\text { many terms are } \\
\text { displayed in the } \\
\text { application }\end{array}$ & & & & & & \\
\hline 3 & $\begin{array}{l}\text { Enter the } \\
\text { keyword farm } \\
\text { term completely } \\
\text { and how many } \\
\text { results are the } \\
\text { terms displayed } \\
\text { in the } \\
\text { application? }\end{array}$ & $\begin{array}{c}66.67 \\
\%\end{array}$ & $\begin{array}{c}9.52 \\
\%\end{array}$ & $\begin{array}{c}12.70 \\
\%\end{array}$ & $\begin{array}{c}4.76 \\
\%\end{array}$ & $\begin{array}{c}6.35 \\
\%\end{array}$ & $66.67 \%$ \\
\hline
\end{tabular}

On the aspect of system design, the system suitability aspects and system ease aspects of the results of the questionnaire will determine the level of user satisfaction with the application being built. The results of the questionnaires distributed were tabulated by giving a 5-4-3-2-1 Likers scale value then the data was calculated using the following formula:

$\mathrm{X}=\frac{N}{y . z} \times 100 \% \quad$ Description: $\mathrm{X}=$ Percentage Value $\mathrm{y}=$ maximum score

$\mathrm{N}=$ Number of Scale Respondents $\mathrm{z}=$ Number of Respondents 
JOSAR, Vol. 1 No. 1 March, 2018; p-ISSN: 2502-8251; e-ISSN: 2503-1155

Copyrights@ Balitar Islamic University, Blitar-Indonesia https://ejournal.unisbablitar.ac.id/index.php/josar

Table 2 Testing the efficiency of the Boyer Moore algorithm

\begin{tabular}{|c|c|c|c|c|c|c|c|}
\hline \multirow[t]{2}{*}{ No. } & \multirow[t]{2}{*}{ Pertanyaan } & \multicolumn{5}{|c|}{ Skala } & \multirow[t]{2}{*}{$\begin{array}{c}\text { Presentase } \\
\text { Hasil }\end{array}$} \\
\hline & & 5 & & 3 & 2 & 1 & \\
\hline 1 & $\begin{array}{l}\text { Do you feel preloading this } \\
\text { application fast? }\end{array}$ & 0 & 27 & 11 & 22 & 3 & $59 \%$ \\
\hline 2 & $\begin{array}{l}\text { Did you find the term you } \\
\text { were looking for? }\end{array}$ & 3 & 34 & 17 & 9 & 0 & $69 \%$ \\
\hline 3 & $\begin{array}{l}\text { Do search results display } \\
\text { the information you need? }\end{array}$ & 2 & 23 & 11 & 27 & 0 & $60 \%$ \\
\hline 4 & $\begin{array}{l}\text { Are the main features of the } \\
\text { search feature easy to use? } \\
\mathrm{s} \text { the whole dictionary } \\
\text { application the term farm is }\end{array}$ & 18 & 31 & 12 & 2 & 0 & $80 \%$ \\
\hline 5 & $\begin{array}{l}\text { easy to use (menu, form) } \\
\text { without having to read the } \\
\text { information on how to use } \\
\text { it? }\end{array}$ & 16 & 26 & 19 & 2 & 0 & $78 \%$ \\
\hline 6 & $\begin{array}{l}\text { Do you think this dictionary } \\
\text { term farm application is } \\
\text { quick to find the meaning of } \\
\text { the term searched? } \\
\text { Does the font size on the } \\
\text { search results page make it }\end{array}$ & 8 & 30 & 22 & 3 & 0 & $73 \%$ \\
\hline 8 & $\begin{array}{l}\text { easy for you to find the term } \\
\text { you're looking for in the } \\
\text { term dictionary application? } \\
\text { Does the font color on the } \\
\text { search results page make it }\end{array}$ & 2 & 40 & 19 & 2 & 0 & $73 \%$ \\
\hline 9 & $\begin{array}{l}\text { easier for you to find the } \\
\text { term you are looking for in } \\
\text { the term dictionary } \\
\text { application? }\end{array}$ & 7 & 45 & 7 & 3 & 1 & $77 \%$ \\
\hline 10 & $\begin{array}{l}\text { Does the overall color } \\
\text { selection of the application } \\
\text { make you comfortable } \\
\text { using this application? }\end{array}$ & 6 & 37 & 13 & 7 & 0 & $73 \%$ \\
\hline 11 & $\begin{array}{l}\text { Are you interested in } \\
\text { revisiting the term farm } \\
\text { dictionary application? }\end{array}$ & 9 & 39 & 12 & 1 & 2 & $76 \%$ \\
\hline 12 & $\begin{array}{l}\text { Are you interested in } \\
\text { recommending the term } \\
\text { dictionary application to } \\
\text { friends, relatives, or others? }\end{array}$ & 4 & 37 & 18 & 1 & 3 & $72 \%$ \\
\hline
\end{tabular}


JOSAR, Vol. 1 No. 1 March, 2018; p-ISSN: 2502-8251; e-ISSN: 2503-1155

Copyrights@ Balitar Islamic University, Blitar-Indonesia https://ejournal.unisbablitar.ac.id/index.php/josar

Beta test results with questionnaires to users to assess aspects of system design, system simplicity, and system suitability in the dictionary application the term livestock get an average value of as many as:

$$
\begin{aligned}
& =\frac{\text { jumlah dari presentase tiap pertanyaan }}{\text { jumlah pertanyaan }} \\
& =\frac{\left(X_{1}+X_{2}+X_{3}+X_{4}+X_{5}+X_{6}+X_{7}+X_{8}+X_{9}+X_{10}+X_{11}+X_{12}\right) \%}{12} \\
& =\frac{(59+69+60+80+78+73+69+73+77+73+76+72) \%}{12} \\
& =\frac{859 \%}{12} \\
& =71.58 \%
\end{aligned}
$$

\section{CONCLUTION}

\section{A. Conclution}

Based on the results of research, design, discussion, and testing with the title "Application of String Matching Using Boyer Moore's Algorithm in the Application Dictionary of Animal Husbandry" conclusions can be drawn as follows:

1. The process of designing a dictionary application of the term farm by applying string matching using the Boyer Moore algorithm starting from the Flowchart includes the flowchart program and flowchart method.

2. The term dictionary application is successfully implemented in webbased applications PHP and MysQLi database.

3. Testing the application carried out using beta testing with a questionnaire shows the results that the dictionary application of the term farm gets a value of $71.58 \%$. This means that users have high satisfaction that there is an application. Beta testing of the term farm dictionary application includes aspects of 
JOSAR, Vol. 1 No. 1 March, 2018; p-ISSN: 2502-8251; e-ISSN: 2503-1155

Copyrights@ Balitar Islamic University, Blitar-Indonesia

https://ejournal.unisbablitar.ac.id/index.php/josar

application design, ease of application and appropriateness aspects of the application.

\section{B. Suggestion}

Based on the results of research, design, discussion and testing of the dictionary application of the term livestock, in this study can be suggested several things as follows:

1. Development of a dictionary of terms in other fields of science

2. Development of a dictionary application term that can be applied with the latest technology for example Android

3. Development of the term dictionary application can be used by entering the term meaning keywords so that the application displays the terms entered according to the meaning entered by the user.

4. Development using the auto-correction feature in the dictionary term

5. Development using semantic search

\section{REFERENCES}

[1] Departemen Pendidikan Nasional. 2008. Kamus Besar Bahasa Indonesia (KBBI). Edisi 4. Jakarta: Gramedia Pustaka Utama

[2] Undang-Undang No.18 tahun 2009 Tentang Peternakan Dan Kesehatan Hewan

[3] Damar, Agustinus Mario. 2016. 3 Fakta Mengejutkan Pengguna Internet di Indonesia.(online) (https://www.google.co.id/amp/s/m.liputan6.com/amp/2435997/3-faktamengejutkan-pengguna-internet-di-indonesia diakses 25 Desember 2017)

[4] Effendi, Ilham. 2017. 10 Search Engine (Mesin Pencari) Terpopuler di Dunia. (online) (https://www.it-jurnal.com/10-search-engine-terpopulerdi-dunia diakses 3 Januari 2018)

[5] Adjeroh, Donald dkk. 2008. The Burrows-Wheeler Transform : Data Compression, suffix Arrays, and Pattern matching. Jerman: Springer Science and Business Media, LLC

[6] Puntambekar, A. 2008. Analysis \& Design of Algorithms. Edisi Pertama. India: Technical Publications Pune

[7] Ramadhansyah, 2013. Perancangan Aplikasi Kamus Bahasa Gayo dengan menggunakan metode Boyer Moore . Jurnal Pelita Informatika Budi Dharma Vol.4 No.3. hal 118-122 